\title{
A emergência da América do Sul na agenda da política externa brasileira nos governos Lula da Silva (2003-2010)
}

La emergencia de la América del Sur en la agenda de la política externa brasileña en los gobiernos de Lula da Silva (2003-2010)

L'émérgence de l'Amérique du Sud dans la politique extérieure brésilienne pendant les gouvernements Lula da Silva (2003-2010)

The emergency of the South America in the agenda of the Brazilian external politics in the governments Lula da Silva (2003-2010)

\section{Jorge Luiz Raposo Braga}

\section{(2) OpenEdition}

\section{Journals}

Edição electrónica

URL: http://journals.openedition.org/espacoeconomia/2803

DOI: $10.4000 /$ espacoeconomia.2803

ISSN: 2317-7837

\section{Editora}

Núcleo de Pesquisa Espaço \& Economia

Refêrencia eletrónica

Jorge Luiz Raposo Braga, «A emergência da América do Sul na agenda da política externa brasileira nos governos Lula da Silva (2003-2010)», Espaço e Economia [Online], 10 | 2017, posto online no dia 15 julho 2017, consultado o 20 abril 2019. URL : http://journals.openedition.org/ espacoeconomia/2803; DOI : 10.4000/espacoeconomia.2803

Este documento foi criado de forma automática no dia 20 Abril 2019.

(c) NUPEE 


\title{
A emergência da América do Sul na agenda da política externa brasileira nos governos Lula da Silva (2003-2010)
}

\author{
La emergencia de la América del Sur en la agenda de la política externa \\ brasileña en los gobiernos de Lula da Silva (2003-2010) \\ L'émérgence de l'Amérique du Sud dans la politique extérieure brésilienne \\ pendant les gouvernements Lula da Silva (2003-2010) \\ The emergency of the South America in the agenda of the Brazilian external \\ politics in the governments Lula da Silva (2003-2010)
}

Jorge Luiz Raposo Braga

\section{Introdução}

1 Na década de 2000, a emergência de uma nova configuração política na América do Sul decorrente do fiasco das promessas neoliberais favoreceu a ascensão de presidentes com apoio das diferentes matrizes culturais, formadoras dos movimentos sociais, e dos diversos segmentos do empresariado nacional descontentes com as medidas de abertura comercial, conduzidas indiscriminadamente pelos governos anteriores. As mudanças nas condições materiais do Brasil se alteraram em virtude do cenário econômico internacional positivo, trazendo a cena o presidente Lula da Silva, do Partido dos Trabalhadores (PT).

2 Na escala regional-global, o governo Lula deslocou a trajetória da política externa da esfera defensiva em direção a posições mais proativas. 0 objetivo era recuperar o vetor de atuação do país por intermédio da constituição de coalizões Sul-Sul para intervir no ordenamento internacional através das organizações intergovernamentais (OIG's). Conquanto, o discurso oficial procurou valorizar a América do Sul na agenda brasileira e a 
integração regional como instrumento funcional, na intenção de assegurar maior autonomia do país no espaço mundial. Dentro desse contexto, o Brasil ocupou um lugar singular ao promover iniciativas de expressão política e econômica sul-americanas, como por exemplo, a criação da UNASUL (União das Nações Sul-Americanas) e a ampliação dos investimentos de empresas brasileiras por intermédio do BNDES (Banco Nacional de Desenvolvimento Social). Desse modo, a política externa e o Ministério das Relações Exteriores aumentaram o seu grau de prioridade na administração petista com forte rebatimento nas relações do Brasil com a região.

3 Nos últimos anos têm-se produzido uma diversidade de trabalhos acerca da administração Lula da Silva em diferentes campos do conhecimento. As abordagens constituem-se em esquemas teóricos e analíticos sustentados preferencialmente na dimensão econômica e/ ou política, porém, raramente espacial. Este trabalho se inscreve em um esforço interpretativo na perspectiva brasileira sobre as práticas adotadas pelo presidente Lula da Silva no âmbito dos projetos regionais. O debate integracionista tornou-se relevante em função de ainda ser um tema persuasivo na agenda da política externa dos países sulamericanos. Entretanto, os resultados são limitados e têm revelado o descompasso entre o discurso diplomático brasileiro e suas ações no fortalecimento da integração regional.

\section{Mudanças no perfil da política externa brasileira}

4 A crescente presença brasileira no espaço regional, em especial, após a primeira eleição do presidente Lula da Silva, reacendeu os debates sobre a retomada do projeto do país à condição de "potência regional" e "global". As discussões estão pautadas nas ações políticas, econômicas, sociais, militares e culturais colocadas em curso pelo Brasil, e sustentadas na articulação entre a agenda doméstica e a estratégia de inserção internacional. Embora a política externa do governo Lula operasse sobre a matriz que foi esboçada já no final do segundo governo Fernando Henrique Cardoso (FHC), no período de 1999 a 2002, a correção de rumos em direção a matriz de contornos novodesenvolvimentistas ${ }^{1}$ deu maior visibilidade às proposições idealizadas pela administração petista, já em seu primeiro mandato. As escolhas do Embaixador Celso Amorim ao Ministério das Relações Exteriores, do Embaixador Samuel Pinheiro Guimarães como Secretário-Geral e do Professor Marco Aurélio Garcia a assessoria da presidência para assuntos internacionais promoveram a tônica desse modelo desenvolvimentista e autonomista no interior do Itamaraty.

5 O redimensionamento do Itamaraty ocorreu por meio do aumento no quadro de diplomatas, da elevação dos recursos financeiros, da abertura de novas embaixadas na África e na Ásia, das alterações no processo de seleção de diplomatas, entre outros, indicavam as pretensões do Brasil nas relações internacionais. Essas mudanças são assinaladas por CERVO (2008) em três pontos centrais, a saber: a) a defesa do multilateralismo de reciprocidade nas negociações comerciais a partir da formação de coalizões entre "países emergentes", com intuito de discutir a natureza das regras não somente no regime do comércio internacional, mas também em outras temáticas; b) o enfrentamento da dependência estrutural em diferentes esferas (financeira, empresarial e tecnológica) através de parcerias estratégicas, de novo enfoque nas relações Norte-Sul e da Cooperação Sul-Sul ${ }^{2}$; c) a intenção de constituir a América do Sul como polo de poder e plataforma política para a expansão dos empreendimentos brasileiros ao exterior. 
6 Desde os anos 2000 o Brasil vem ao mesmo tempo aumentando a sua capacidade de projetar-se e de ser reconhecido como ator importante nas discussões das principais questões internacionais. Para tanto, o país buscou estabelecer um diálogo mais próximo as "potências emergentes" (China, Índia e África do Sul, entre outras) e no âmbito do MERCOSUL, a diplomacia brasileira objetivou construir um projeto estratégico que não só ressaltasse os interesses econômicos, mas resgatasse a dimensão política do processo de integração, constituindo assim, as chamadas parcerias estratégicas (SARAIVA, 2007). Procurando afastar a política externa de sua característica defensiva e de sustentáculo da estabilidade macroeconômica dos períodos anteriores, o governo Lula da Silva a conduziu para a posição mais ofensiva e pragmática, objetivando: "a manutenção da estabilidade econômica; a retomada do papel do Estado na coordenação de uma agenda neodesenvolvimentista; a inclusão social e a formação de um expressivo mercado de massas. (HIRST, SOARES DE LIMA e PINHEIRO, 2010, p.1)

7 A política de Lula da Silva buscou aproveitar as experiências do seu partido, o PT (Partido dos Trabalhadores), nas prefeituras de vários estados brasileiros para a construção do Plano Plurianual (PPA 2004-2007). A estratégia visava identificar os principais problemas a serem enfrentados, como a concentração social e espacial de renda, a pobreza, a degradação ambiental, a cidadania, o desemprego e a transformação dos ganhos de produtividade em aumento de renda para os trabalhadores (LESSA, COUTO e FARIAS, 2009). Tais proposições domésticas foram elencadas para a política externa brasileira, o que tornou o Brasil possível "porta voz" para os demais "países do Sul".

A fórmula adotada pelo governo Lula tem sido vincular um novo acervo de políticas sociais que atacam a pobreza e a desigualdade no plano doméstico com uma ativa diplomacia presidencial. Ao mesmo tempo em que se transformou a questão social numa bandeira de política externa(...) (HIRST, SOARES DE LIMA e PINHEIRO, 2010, p.6).

8 No plano global, o governo Lula da Silva utilizou a credibilidade do país, propondo consensos com os demais "países emergentes" como forma de contrapor as ações unilaterais das grandes potências nas discussões dos organismos internacionais. De maneira pragmática, o Brasil aproveitou as lacunas deixadas pela política de securitização do presidente estadunidense, George W. Bush, após o onze de setembro de 2001, para ampliar as exportações de bens e serviços e expandir os negócios do empresariado brasileiro. Baseado no multilateralismo universal, o Brasil articulou junto aos governos da Índia, da China, da África do Sul, entre outros, a criação do G-20 Comercial no âmbito da Organização Mundial do Comércio (OMC), a partir de 2003, em Cancun. A intenção era debater o tratamento dado pelos "países centrais" as questões referentes à abertura dos mercados, visto que a posição da Europa e dos Estados Unidos pressionava os "países do Sul" a liberalizar a importação de produtos industriais e serviços sem contrapartida para as exportações dos produtos agrícolas desses países. A falta de propostas consistentes sobre a suspensão das barreiras alfandegárias e a concessão de subsídios que distorcem o comércio agrícola internacional em favor dos produtores europeus e norte-americanos levou os negociadores brasileiros a se colocarem contrários aos termos apresentados. Tal fato propiciou aos "países do Sul" a defesa de uma posição comum na OMC. Porém, o embate entre os dois grupos paralisou as negociações da Rodada de Doha em 2006 e o impasse prosseguiu até o final da década.

9 A crise financeira e econômica iniciada em 2008 nos Estados Unidos e estendida a Europa em 2009 produziu incertezas no cenário internacional. O G-8 que reunia os sete países 
mais ricos, mais a Rússia, incorporou os "países emergentes" como Brasil, China, Índia e África do Sul nas discussões sobre a governança econômica global. A posição brasileira que foi vencedora defendeu o aumento no número de países nos esforços para conter os efeitos perversos da desregulamentação financeira. Assim, o G-8 perdeu efetividade e, em seu lugar, entrou em cena o G-20 financeiro, cuja primeira reunião ocorreu em novembro de 2008 na cidade de Washington e a segunda em abril de 2009 em Londres. Diante dos efeitos da estagnação econômica, o governo brasileiro adotou três iniciativas: a intensificação dos investimentos internos através do Programa de Aceleração do Crescimento (PAC), a consolidação de coalizões ao sul com objetivo de obter apoio para as reformas do sistema financeiro internacional, do Fundo Monetário Internacional (FMI) e do Banco Mundial e destinou dez bilhões de dólares ao FMI com o objetivo de aumentar os aportes de capital dessa instituição (CERVO e BUENO, 2012).

Nos foros ambientais, como por exemplo, sobre Mudança do Clima (COP 15), o Brasil adotou uma postura mais assertiva ao propor metas de redução de emissão de carbono e cobrar maior responsabilidade dos países mais poluidores. Posteriormente, esse desempenho resultou no acordo para a realização da Rio +20 , a Conferência das Nações Unidas sobre Desenvolvimento Sustentável (VISENTINI, 2013).

$11 \mathrm{Na}$ esfera da segurança coletiva, a diplomacia brasileira criticou a ação preventiva unilateral estadunidense, a doutrina da ingerência europeia e o terrorismo, enaltecendo a importância do Brasil nos processos de solução de conflitos e manutenção da paz. Para isso defendeu a democratização das decisões do Conselho de Segurança da ONU e, com intuito de desempenhar papel relevante no campo da segurança, abandonou a posição da não intervenção, ao assumir a liderança da missão de peacekeeping da MINUSTAH (Missão de Estabilização das Nações Unidas no Haiti) a partir de 2004. Ainda nesse tema, por ter uma política externa pacifista e defensora das negociações como mecanismo de solução de conflitos, o país propôs uma reforma no Conselho de Segurança na intenção de tornálo mais representativo diante do cenário do século XXI. Tal proposição contou com apoio de outros países que aspiram à condição de membros permanentes, o chamado G-4 (Brasil, Alemanha, Índia e Japão). "O receio de perda de poder pelos cinco membros permanentes, as rivalidades regionais entre potências e a discordância quanto aos termos da reforma mantêm o Conselho nos moldes obsoletos em que foi criado logo após a Segunda Guerra" (CERVO e BUENO, 2012, p.541).

No plano das parcerias estratégicas e da cooperação Sul-Sul, o Brasil diversificou e expandiu suas relações internacionais. Outras iniciativas relevantes foram à aproximação com o continente africano através das negociações envolvendo o MERCOSUL e a União Aduaneira da África Austral (SACU); do incremento de apoio técnico com a disseminação de informações sobre os biocombustíveis; a cooperação nas áreas de agricultura, saúde, educação, esportes, defesa e promoção dos direitos humanos; do aumento de visitas oficiais de Chefes de Estado entre o Brasil e governos de diferentes Continentes ${ }^{3}$; do reforço nas relações com a Comunidade de Países de Língua Portuguesa (CPLP); da implantação de novas Embaixadas e da presença crescente de empresas brasileiras na economia de diversos países africanos. Em relação ao Oriente Médio, o presidente Lula consolidou a realização de Encontros de Cúpula América do Sul-Países Árabes (ASPA) e acordos de cooperação MERCOSUL-Conselho de Cooperação do Golfo (CCG), defendeu a participação brasileira nos esforços de paz no conflito israelo-palestino, da mesma forma junto a Turquia propôs solução não confrontacional em relação ao programa nuclear iraniano. 
13 A política externa brasileira era favorável a formação de coalizões com "potências emergentes" na convicção que esses países se constituiriam em importantes aliados tanto nas negociações entre suas economias quanto na articulação das diplomacias em diferentes instâncias de decisão global.

A participação do Brasil nos foros de governança global reflete não apenas uma política proativa de constituição de 'coalizões de geometria variável', envolvendo algumas nações emergentes, como os limites derivados das carências de recursos de poder que permitam ao país uma carreira 'solo' em instâncias globais (HIRST, SOARES DE LIMA e PINHEIRO, 2010, p.8).

14 A visibilidade desses países deveu-se ao crescimento acelerado de suas economias diante da recessão vivenciada pelos países mais ricos. Dentre os grupos políticos, destacam-se a criação do IBAS ou G-3 (Índia, Brasil e África do Sul) em 2003, e a institucionalização em 2007, do BRIC (Brasil, Rússia, Índia e China), com posterior adesão da África do Sul em 2010. O primeiro grupo reúne três países-chave na Cooperação Sul-Sul por serem importantes democracias em seus continentes. Além dos interesses globais como a instituição da temática do desenvolvimento e dos problemas sociais na agenda das organizações multilaterais, os países procuram estreitar acordos em setores específicos, como indústria, comércio, agricultura, serviços e tecnologia. Outro ponto relevante é a intenção de concretizar um eixo transoceânico-transcontinental meridional capaz de forjar uma articulação entre seus espaços regionais. Isso ocorre no momento em que o Oceano Atlântico Sul e o Oceano Índico despontam como zona de imensos recursos energéticos e opção para uma base logística do comércio mundial. Daí o desejo dos mesmos em instituir parceria que garanta a manutenção de uma zona de paz para a navegação e bloqueio a qualquer tentativa de militarização por parte das potências extrarregionais.

O segundo grupo se destaca não só pela grandiosidade de sua Geografia, mas por se constituir uma alternativa a ordem global vigente. Por terem economias crescentes, Brasil, Rússia, China e Índia poderiam produzir intensas modificações no panorama geopolítico internacional. A instituição Goldman Sachs, criadora do acrônimo, ressaltava na ocasião, o potencial desses países de se tornarem peças-chave no cenário políticoeconômico mundial, levando os BRICs a receberem maior atenção do meio acadêmico e da imprensa. Assim, o diálogo político dos BRICs em 2006, na intenção de discutir temas comuns deu origem à primeira cúpula em 2009, na cidade russa de Ekaterimburgo, cujo foco esteve centrado na economia. Em 2010, a segunda reunião ocorreu em Brasília, onde as discussões versavam preferencialmente sobre crise financeira e as reformas das instituições. $O$ destaque foi para a assinatura de um memorando de cooperação entre os Bancos de Desenvolvimento dos quatro países, o que possibilitou a criação do Banco dos BRICs em 2014. Entretanto, a pretensa unidade desse bloco esbarra nas diferenças substanciais de seus membros, em termos de peso econômico, importância geopolítica, grau de integração à economia global, diversidade cultural, as condições domésticas, a relação com a potência hegemônica, entre outros. Diante desse quadro, os analistas levantam questionamentos sobre a capacidade de poder que os BRICs possuem para funcionar como um novo pilar da ordem global e ajudar a construir um sistema internacional mais próspero e estável. 


\section{O lugar da América do Sul na agenda da política externa brasileira}

16 As mudanças no quadro de poder mundial promovida pela atmosfera da Guerra Fria levou o Brasil a se adequar ao ambiente mais globalizado. 0 posicionamento mais autônomo permitiu que o país diversificasse os seus parceiros internacionais. Assim, apesar da manutenção da relação vertical Norte-Sul, em particular com os Estados Unidos, a diplomacia brasileira também intensificou o diálogo horizontal Sul-Sul ${ }^{4}$ e o eixo diagonal Sul-Leste, ou seja, com os países "terceiro-mundistas" e com os "países socialistas" respectivamente (VISENTINI, 1999). Essa característica de diversificar parcerias conduziu as práticas da política externa brasileira no contexto pós-Guerra Fria. O forte caráter integracionista utilizou "os processos de integração para estabelecer ou consolidar a rede de cooperação e poder [preferencialmente] ao sul, partindo da América do Sul e avançando para alianças com outras regióes com o fim de realizar sua meta de país globalista" (CERVO e BUENO, 2012, p.548).

17 Os esforços do governo Lula estavam pautados no resgate do papel da política externa brasileira nas relações internacionais. Por isso, o crescente número de viagens era um indicador das pretensões do presidente de tornar o Brasil um global player, isto é, tornar o país membro constante em eventos internacionais, presente nas reuniões de cúpula e nos diálogos com os principais líderes de outros países. Tal intento passava pela constituição de uma diplomacia ativa e afirmativa, por isso era fundamental fortalecer as relações com os países vizinhos, consolidar a América do Sul como área prioritária na agenda nacional e superar o baixo perfil sul-americano na função de eixo alternativo de poder na escala mundial. Assim, dos presidentes brasileiros a visitar os Estados sul-americanos, Lula da Silva foi o que deu maior prioridade a região. Por conseguinte, a invenção da tradição de "sul-americanidade" acoplada à política externa brasileira "não significa a propagação de uma inverdade, mas a reconstrução do mundo a nossa volta, ou seja, um espaço sulamericano organizado que visa restabelecer o prestígio internacional de seus Estados e os afastar do estereótipo latino-americano atrasado e subdesenvolvido" (GALVÃO, 2009, p. 67). Daí, a intenção do discurso oficial em reconstruir o MERCOSUL e privilegiar a integração regional em diferentes esferas (econômica, cultural, social, infraestrutura, segurança, entre outros) no intuito de criar uma zona própria de poder e legitimar a liderança brasileira.

18 A promoção da integração regional estava focada no desenvolvimento do MERCOSUL, acordo originário do reaquecimento das relações diplomáticas e do arrefecimento das tensões entre Brasil e Argentina. Essa reaproximação permitiu aos países a consolidação de um regime de intercâmbio livre e a instituição de uma união aduaneira que foi estendida, pelo Tratado de Assunção de 1991, aos países limítrofes do Cone Sul, o Paraguai e o Uruguai. O MERCOSUL representava um marco histórico importante para a região, pois além de possibilitar o desenvolvimento dos países locais também funcionava como um instrumento de dissuasão entre as duas maiores economias da América do Sul. Essa aproximação favoreceu a constituição de uma área de paz e de confiabilidade mútua, pautada em valores democráticos; tornou o bloco em sujeito de direito internacional com capacidade de negociação em várias esferas; fortaleceu o poder de barganha do Cone Sul como bloco e alavancou a ideia de América do Sul a partir das negociações com a Comunidade Andina na Cúpula de Brasília de 2000 (CERVO, 2002). 
19 Apesar da ampliação do comércio entre os países membros do Tratado de Assunção, o MERCOSUL enfrenta dissonâncias, pois nem sempre as economias do Brasil e Argentina são convergentes, em muitos setores são competidores e não complementares. Quando Lula da Silva assumiu em 2003, o MERCOSUL agonizava em virtude da oscilação cambial promovida pela desvalorização do Real em 1998/1999 e pela crise econômica argentina em 2001. Nos dois países se falava na necessidade de relançá-lo.

A grande prioridade da política externa durante o meu Governo será a construção de uma América do Sul politicamente estável, próspera e unida, com base em ideais democráticos e de justiça social. Para isso é essencial uma ação decidida de revitalização do MERCOSUL, enfraquecido pelas crises de cada um de seus membros e por visões muitas vezes estreitas e egoístas do significado da integração. O MERCOSUL, assim como a integração da América do Sul em seu conjunto, é sobretudo um projeto político. Mas esse projeto repousa em alicerces que precisam ser urgentemente reparados e reforçados (FUNAG - discurso do presidente Lula, 2008, p.14).

20 No entanto, segundo BUENO (2010), havia um descompasso entre os interesses de ambos, pois, a Argentina concebia o bloco como instrumento de expansão de suas exportações, portanto, um negócio. Por conseguinte, agindo com pragmatismo, os argentinos estabeleceram imposições, como as cotas comerciais e as licenças prévias de importação a certas mercadorias brasileiras. Já o Brasil via o MERCOSUL para além do comércio, ou seja, um instrumento de projeção de poder nas negociações internacionais. Assim, segundo FLORES (2006, p.12), “a Argentina não compartilha em igual intensidade o entusiasmo do governo brasileiro por uma nova geografia comercial pautada na diversificação dos atores, com ênfase no 'sul econômico", porque seu potencial é restrito. Desta forma, a união regional encontra-se fragilizada em virtude das assimetrias, perspectivas e interesses distintos entre os parceiros do MERCOSUL. Então, para FLORES (2006), o nacionalismo continua acima do regionalismo e globalismo, dificultando a concretização de uma geografia comercial mais atuante.

21 A preferência pelo aprofundamento das relações com os países vizinhos sustentava-se no desejo de uma maior abertura das economias, mas os resultados esbarraram nas assimetrias ente os Estados e em um modelo voltado para as políticas industriais nacionais que direcionam os seus compromissos para o mercado externo. "A ideia de criar uma economia regional de escala nunca chegou a ser implementada devido a agentes econômicos nacionais que colocaram obstáculos e ao caráter defensivo dos processos de integração na região" (SARAIVA, 2010, p.6). Essas resistências das "burguesias nacionais" tendem colocar em primeiro plano os seus próprios interesses, o que impede qualquer tentativa de formalização de um bloco sul-americano. Tais ações impõem desafios ao Brasil que procura compatibilizar as suas aspirações universalistas e protagonistas ao desejo de liderança regional (VIGEVANI, RAMANZINI JUNIOR e CORREIA, 2008).

A tônica do governo Lula da Silva era revitalizar as relações de cooperação com a América do Sul em virtude das debilidades estruturais do MERCOSUL. As dificuldades de consolidar aliança estratégica com a Argentina tornavam-se mais evidentes por parte da diplomacia brasileira. Segundo RUSSELL e TOKATLIAN (2014), o governo de Néstor Kirchner (2003-2007) procurou dar resposta ao poderio "sul-americano" do Brasil, para isso adotou estratégias que pudessem contrabalançar o peso político econômico do seu vizinho. A inquietação diante de uma eventual hegemonia brasileira na região levou Buenos Aires acompanhar de maneira relutante as pretensões geopolíticas de valorização da América do Sul por Brasília. Dessa forma, como medidas de "proteção", o governo argentino 
buscou retomar a integração no patamar latino-americano ao assinar acordos econômicos e comerciais com o México, na intenção de aproximá-lo do MERCOSUL; via na construção do eixo Santiago-Buenos Aires meio de limitar as aspirações do Brasil no Cone Sul e, apoiava a inserção da Venezuela, de Hugo Chávez, no MERCOSUL como contraponto regional alternativo as intenções do governo Lula. $\mathrm{Na}$ análise de ALBUQUERQUE (2009-2010), as melhores chances para o Brasil exercer a sua liderança tanto no nível regional quanto global era numa região de equilíbrio convergente. Por isso, a intenção era pensar uma nova fase que procurasse a aprofundar a integração com os países vizinhos e, a partir daí, fazer com que a região passasse a ter um papel mais relevante no cenário mundial.

A crença na organização do espaço sul-americano aos olhos de Brasília passava por construir um cenário moldado pela interação entre o Estado e o mercado. Dadas as condições estruturais, segundo CERVO (2008), a estratégia do governo articulou elementos do liberalismo ao desenvolvimentismo de modo que essa experiência permitisse o país agir no cenário global não no papel de coadjuvante, mas de protagonista. A introdução do paradigma logístico firmou-se em termos operacionais com objetivo de elevar o patamar nacional ao nível das nações mais ricas. Essa mescla, iniciada por FHC e consolidada na administração Lula

diferencia-se do paradigma desenvolvimentista, com o qual pode conviver em certa dose, ao transferir à sociedade as responsabilidades do estado empresário. Diferencia-se do normal, consignando ao Estado não apenas a função de prover a estabilidade econômica, mas a de secundar a sociedade na realização de seus interesses. Limita a prevalência absoluta do Estado que caracterizava o primeiro e elimina do segundo a crença anticientífica no poder ilimitado do mercado de prover tudo o mais (CERVO, 2008, p.86).

o paradigma logístico se apresentava como experiência brasileira e latino-americana em que o Estado conduzia a política externa para atender os "interesses nacionais". No entanto, conforme assinala POULANTZAS (1978), o Estado é arena de luta entre as classes dominantes, portanto, a política externa traz no seu bojo os interesses das classes ou frações hegemônicas no interior do bloco no poder, ou mesmo, de alianças entre as classes. Assim, por intermédio de uma atuação mais assertiva da diplomacia brasileira, os grandes empreendimentos de empresas estatais e de alguns grupos nacionais privados tiveram seus objetivos econômicos se expandindo sobre os países vizinhos e no interior de nações extracontinentais (principalmente em países africanos) por intermédio do Banco Nacional de Desenvolvimento Econômico e Social (BNDES).

Na América do Sul, as empresas brasileiras adquiriram através das fusões e incorporações várias empresas locais e/ou tiveram acesso a exploração de recursos naturais na região. Esse movimento de "transbordamento" da economia brasileira em direção aos países sulamericanos foi impulsionado pela valorização das commodities e respaldado pelos investimentos diretos brasileiros, capitaneados nas linhas de crédito do BNDES a juros subsidiados. O objetivo do financiamento promovido pelo BNDES visava aumentar mercados aos empreendimentos brasileiros no exterior e produzir grandes saldos na balança comercial. Assim, a internacionalização do Banco apoiada em políticas públicas possibilitou que os interesses da burguesia interna se fizessem cada vez mais presentes nos projetos de integração regional sul-americanos. Portanto, a política externa do presidente Lula vinculada à dinâmica do plano doméstico tornou-se um instrumento importante para a atuação internacional dessa fração de classe. Outra medida importante adota pelo governo brasileiro foi abrir em 2009, na cidade de Montevidéu, o primeiro 
escritório do BNDES no exterior. A cidade uruguaia possui localização estratégica por sua centralidade em negócios no MERCOSUL e ser a Capital da ALADI (Associação LatinoAmericana de Desenvolvimento e Integração). 0 escritório visa funcionar como apoio aos projetos de integração e de infraestrutura, a facilitação das atividades das empresas brasileiras na região e a cooperação técnica.

A existência de conflitos entre as frações de classe que compõem a burguesia interna no interior do bloco no poder, não impediu a aglutinação dessas frações em defesa de interesses comuns nos planos regional e mundial. A orientação da política externa brasileira nos governos Lula estava associada às mudanças que ocorriam no ambiente doméstico. Nesse sentido, a ascensão da grande burguesia interna industrial e agrária influenciou a atuação internacional do Estado brasileiro, definindo suas prioridades, estratégias e espaços de acumulação de capital. Daí decorre um discurso presidencial mais afinado junto os desejos da burguesia interna, a saber: i) o fortalecimento das relações Sul-Sul contribui para a diversificação dos mercados e, consequentemente, amplia as oportunidades de investimentos; ii) a priorização da América do Sul como plataforma de expansão dos negócios brasileiros interfere no ordenamento territorial vigente; iii) a desenvoltura nas seguintes negociações: as multilaterais, tendo como caso expressivo a atuação na Organização Mundial do Comércio (OMC), onde o governo Lula procurava dar suporte aos grandes produtores agrícolas ao se posicionar contrário aos subsídios e ao protecionismo dos países mais ricos que prejudicavam a competitividade do agronegócio nacional; as bilaterais, representadas pela negociação entre MERCOSUL-União Europeia como contraponto as pressões norte-americanas em defesa de uma integração hemisférica e as regionais, exemplificadas pelo arquivamento da Área de Livre Comércio das Américas (ALCA), principalmente pela medidas unilaterais estadunidenses e iv) o impulso à internacionalização das empresas brasileiras em setores intensivos em recursos naturais e no setor financeiro com a crescente expansão dos bancos (BOITO JUNIOR e BERRINGER, 2013).

Por certo, iniciativas brasileiras deram densidade ao diálogo com os países vizinhos no intuito de estruturar um novo arranjo regional que promovesse à expansão das relações econômicas entre seus membros, a propagação dos valores democráticos nacionais e o apoio automático as aspirações globais do Brasil. Essas questões exigiram maior esforço do país para ir além da mera integração comercial, possibilitando outras formas de cooperação regional. Daí, a relevância da América do Sul "teve menos a ver com novas ideias sobre governança coletiva ou sobre uma suposta identidade regional comum do que com um cálculo instrumental calcado em considerações de poder e autonomia" (SPEKTOR, 2010, p. 34). Trata-se, portanto, da crescente presença brasileira na ingerência dos assuntos sul-americanos, o que tem gerado desconfianças na redondeza sobre as intenções das propostas do Brasil. Nas análises de SORJ e FAUSTO (2011), esse temor dos vizinhos perpassa pelo enfrentamento da aliança entre as empresas nacionais e o Estado brasileiro. A percepção ganha efeito não somente em função da assimetria das economias, mas principalmente na capacidade estatal do Brasil de responder aos interesses da burguesia interna tanto no âmbito doméstico quanto no interior dos países da região ${ }^{5}$.

o desafio do paradigma logístico consiste em reforçar o núcleo duro nacional, torná-lo competitivo e alçá-lo ao nível comparativo das nações mais ricas. Conquanto, cabe ao Estado empresário restringir a vulnerabilidade externa por meio da canalização de recursos para robustecer os empreendimentos públicos e, principalmente os privados, estimulando-os a expansão global, a iniciar pela vizinhança. De acordo com CERVO (2008), 
a conduta logística a partir do governo Lula modificou as relações do Brasil com seus vizinhos através do aumento de suas capacidades de poder. Segundo o autor, três requisitos podem ser observados. Em primeiro lugar, o reconhecimento da interdependência real da globalização supõe a incorporação das vantagens comparativas intangíveis à administração das relações exteriores. Em segundo lugar, ocorre a crença na integração regional como instrumento de acúmulo de poder, tanto próprio quanto dos membros do bloco em construção. Em terceiro lugar, o encaminhamento do processo de internacionalização da economia nacional elenca a América do Sul em plataforma de expansão dos negócios brasileiros.

29 A estratégia regional do Itamaraty e o ativismo do presidente Lula conferiam densidade aos acordos sul-americanos. A iniciativa da Integração da Infraestrutura Regional SulAmericana (IIRSA) representava o avanço em direção à integração funcional dos territórios por meio da construção da infraestrutura em transportes, energia e telecomunicações. A idealização dos megaprojetos e as centenas de obras prometiam redesenhar a Geografia da América do Sul, abrindo oportunidades às empresas brasileiras, principalmente no momento em que a retomada da política de desenvolvimento do BNDES atua na interface com as diretrizes do paradigma logístico de incentivo ao empresariado. "Esse foi um momento de grande êxito da logística internacional de Lula, em razão do ritmo forte que ostenta e da segurança que a reverso imprime à economia nacional" (CERVO, 2008, p.89). O entusiasmo pela intensificação das relações Sul-Sul, apontava para uma maior articulação do país com a América do Sul, já que o presidente defendia que o aumento da complementaridade entre as economias poderia consolidar um desenvolvimento da região. $\mathrm{O}$ discurso pautado numa política de cooperação técnica e na instalação de uma infraestrutura mais moderna permitiu o avanço das oportunidades de negócios para empresas brasileiras como a Petrobrás, Banco do Brasil, Odebrecht, Camargo Correa, Gerdau, Votorantim, Vale do Rio Doce, JBS, Companhia Siderúrgica Nacional, entre outras.

Em suma, os efeitos das crises da década de 1990, a conjuntura internacional balizada pela emergência de um eixo de desenvolvimento constituído pelas "potências emergentes" (China, Índia, África do Sul e Rússia) e as transformações regionais que redesenham a geopolítica através da ascensão de governos de "ideologia desenvolvimentista", renovam as possibilidades de se constituir uma integração multinível. Somados a isso, o crescimento econômico e a demanda por energia em países como os Estados Unidos e a China, a partir de 2003, elevaram os preços das commodities e a competitividade internacional. Por ter enormes disponibilidades de recursos naturais, a América do Sul foi elencada ao jogo geopolítico dos governos e dos atores transnacionais, principalmente das "empresas transnacionais" (ETNs). Assim, a posição do presidente Lula era aprofundar a política de desenvolvimento da infraestrutura física regional esboçada pelo segundo mandato do governo FHC, na primeira Cúpula de países sul-americanos em Brasília, em 2000, que originou a criação da IIRSA. Posteriormente, houve o aumento dos investimentos brasileiros diretos na região, o que tensionou as relações entre sociedades, governos e empresas brasileiras devido ao encaminhamento dos projetos direcionados a setores intensivos em recursos naturais e de grandes impactos sociais e ambientais.

31 A visibilidade da diplomacia brasileira no plano sul-americano obteve avanços, principalmente na esfera política e na segurança, embora os resultados na área econômica ainda se mantêm limitados. Dessa forma, no final de 2004, o Brasil procurou encaminhar ações mais concretas para a criação da Comunidade Sul Americana de Nações 
(CASA), depois rebatizada em 2007 de União de Nações Sul-Americanas (UNASUL), incluindo também o Suriname e a Guiana. A UNASUL se constitui locus de diálogo para tratar de temas político, da integração física do território, do meio ambiente, da integração energética, dos mecanismos financeiros, entre outros, demonstrando o seu interesse na cooperação técnica e financeira.

Segundo SARAIVA (2010), a UNASUL se aproxima mais de um instrumento de governança regional do que dos modelos clássicos de integração, já que tem um caráter estritamente intergovernamental e de institucionalidade limitada. Por isso ela pode acomodar diferentes iniciativas sub-regionais como o MERCOSUL, a Comunidade Andina ou a Alternativa Bolivariana das Américas (ALBA). Assim, para o Brasil, "ampliar a institucionalidade do bloco por mecanismos supranacionais significaria engessamentos e limitações advindas de uma governança regional que poderiam limitar as pretensões internacionais do Brasil (DUPAS e OLIVEIRA, 2008, p.241).

O interesse pelos processos de integração econômica é decorrente das mudanças no Sistema Mundial que tem produzido uma variedade de acordos regionais, sub-regionais e bilaterais, despertando em diferentes atores oportunidades de inserção mais eficiente e ativa no comércio internacional. Essas possibilidades de ampliação dos mercados, de acesso as cadeias produtivas, da recepção de investimentos, da projeção de liderança regional, mobilizaram os países sul-americanos a compor diferentes arranjos cooperativos. Então, na década de 2000, a tendência se traduziu em estratégias diversas. De um lado alguns países (principalmente Chile, Peru e Colômbia) firmaram Tratados de Livre Comércio (TLCs) com Estados Unidos e União Europeia para bens e serviços, estabilidade de regras e proteção aos investimentos estrangeiros. De outro, consolidou-se posições (Argentina, Brasil, Venezuela, Bolívia e Equador) mais resistentes a abertura comercial expressiva e a desconfiança em aderir a regras não estritamente voltadas ao comércio nos acordos. Além disso, registram-se também, alguns países que expropriaram ativos estrangeiros (Venezuela e Bolívia). Assim, as divergências entre as estratégias nacionais ameaçam levar os projetos integracionistas à crise. Isso ilustra as clivagens políticas que impedem a decolagem do "regionalismo pós-liberal" e coloca em debate o papel que se poderia esperar do Brasil como vetor de integração regional (MOTTA VEIGA e RIOS, 2011).

\section{Dilemas e desafios e a liderança brasileira na América do Sul}

A estratégia da política externa do governo Lula visava à busca pelo desenvolvimento com autonomia, para isso tornava-se fundamental a diversificação das parcerias econômicas na intenção de respaldar o projeto por maior protagonismo no sistema internacional (VIGEVANI e CEPALUNI, 2007). Portanto, as suas relações com o mundo estão ancoradas no sucesso da liderança regional (ALBUQUERQUE, 2009-2010). O fato de erigir a América do Sul na agenda brasileira perpassa pela expertise diplomática de dar sentido geográfico e identitário a região. A tarefa de criar consenso sobre a integração regional objetivava desviar a atenção do cálculo de poder que estava embutido na reinvenção conceitual ${ }^{7}$. "Existia, então, a percepção de que a integração regional seria funcional para o Brasil desempenhar o papel de player global, e o prognóstico de certa divisão de influência do espaço geopolítico e econômico com os Estados Unidos" (SORJ e FAUSTO, 2011, p. 12). 

projeto maior: a tendência à fragmentação regional; a necessidade de conviver num clima de pluralismo ideológico; a interpretação do tema das lideranças como uma fortaleza para a coletividade. Tais desafios tende a exigir do Brasil maior flexibilidade em suas decisões, já que se no meio internacional o país possui um ativismo reconhecido, no contexto regional existe uma inconsistência de sua posição e de sua atuação como líder. Mesmo que haja uma afinidade ideológica entre os presidentes isso não significa aceitação automática às posições do Brasil nos temas regionais e internacionais8. "Para não perder apoio político doméstico, essas lideranças por vezes exacerbam seus discursos e práticas de política externa. (...) a nova onda sul-americana de líderes 'esquerdistas' (...) acaba por operar contra essa tendência" (DUPAS e OLIVEIRA, 2008, p.239).

As capacidades materiais e o peso político assimétricos do Brasil comparados aos demais países sul-americanos não o credencia a uma liderança ${ }^{9}$ inconteste. 0 país tem lidado com situações de conflitos na área econômica envolvendo interesses do empresariado nacional e governos e sociedades de países por onde se estendem o capitalismo brasileiro. 0 quadro complexo impõe desafios de escolhas ao Brasil, ou seja, preferir jogar na escala global ou ter influência política real na região. "Os limites e possibilidades da atuação do Brasil como vetor de integração regional requer a análise das condicionantes econômicas, das estratégias de inserção internacional dos países sul-americanos e das prioridades brasileiras em suas relações com a região e com o mundo" (MOTTA VEIGA e RIOS, 2011, p.73). O dilema para o governo brasileiro, então, passaria especialmente, "por optar pelo tipo de liderança mais compatível com seus objetivos e, sobretudo, com seus recursos de poder" (ALBUQUERQUE, 2009-2010, p.17).

No entanto, a liderança brasileira tem enfrentado posicionamentos reativos justamente na área eleita como prioritária. A América do Sul tem reforçado seu caráter diverso e heterogêneo, principalmente no momento em que os países procuram reorientar os interesses e objetivos no relacionamento com o Brasil. Na análise de MOTTA VEIGA e RIOS (2011), nos últimos anos, os países sul-americanos e os atores que intervém na arena de política externa adotam preferências políticas e econômicas distintas frente ao seu grande vizinho regional. No grupo dos países revisionistas (Argentina, Bolívia, Equador e Venezuela), a política externa foi conduzida muitas vezes pelas práticas da política doméstica, assim as relações com o Brasil foram convergentes quando o conteúdo era essencialmente político ou reticente aos mecanismos e regimes internacionais de regulação. Entretanto, quando o assunto diz respeito à esfera econômica bilateral, esses países fazem outra leitura do tipo "Norte X Sul", comportando-se como "países do Sul" diante da potência "imperialista"10. No tocante ao grupo de países (Chile, Colômbia e Peru) que seguiu com mais afinco as diretrizes neoliberais da década de 1990, o mesmo adota posturas menos entusiasmadas em relação às iniciativas políticas regionais de Brasília. A intenção dos governos e empresários daqueles países é melhorar a participação de seus produtos no mercado brasileiro e atrair investimentos de empresas do Brasil, o que reforçaria a sua posição de apoio a um projeto liberalizante regional. Finalmente, Uruguai e Paraguai, apesar de terem fortes relações econômicas dentro do MERCOSUL se sentem negligenciados por Brasil e Argentina. Dessa forma, aqueles países têm acenado para propostas que os aproximam das agendas de Peru e Colômbia. Neste cenário, onde as estratégias nacionais são cada vez mais divergentes, os autores citados apontam que os esforços políticos realizados no âmbito da UNASUL tampouco conseguiram superar os obstáculos impostos pelo nacionalismo econômico e o predomínio das agendas 
domésticas sobre a regional. Dessa forma, o projeto de integração sul-americana parece cada vez mais confinado à retórica.

Embora a importância do Brasil na agenda externa dos países do entorno parece ter crescido, ainda permanecem em aberto questões-chave sobre a percepção dos vizinhos acerca da liderança regional brasileira. Por conseguinte, o governo brasileiro enfrenta desafios quanto às expectativas dessas nações em relação ao peso do país na América do Sul. SOARES DE LIMA e HIRST (2009, p. 16-17) assinala tal dilema: “(...) o tamanho econômico do país é quase a metade de toda a região respectiva, o que acirra o temor de pretensões hegemônicas e, simultaneamente, fortes expectativas de cooperação e de tratamento diferenciado". Essas visões reacendem os questionamentos sobre a capacidade e o interesse de Brasília em conduzir o ativismo regional.

$\mathrm{Na}$ análise de SPEKTOR (2010), a ausência no Brasil de um consenso que apóie uma política mais articulada aos anseios da região, favoreceu uma baixa expectativa na vizinhança sobre os compromissos ou preocupações brasileiras voltadas para o projeto regional. Assim, como aplacar as desconfianças mútuas, se a "potência regional" parece conduzir a política externa em baixo perfil?

O movimento em direção à região convive com uma política externa que enfatiza soluções nacionais mesmo quando os problemas são compartilhados, busca o desenvolvimento econômico interno, mantêm firmes suspeitas sobre as intenções dos vizinhos, é cautelosa e avessa ao risco. Na vizinhança, a percepção dominante em relação ao Brasil é a de que o país, apesar de ser o principal centro de poder regional, não traduz essa ascendência em liderança amigável. Segundo essa visão, não é fácil seguir o Brasil a reboque. Mesmo que os vizinhos não temam uma suposta dominação brasileira nem tenham uma visão negativa das intenções do Brasil, eles sentem que o país não responde eficazmente à vasta assimetria de poder que marca a região. Paraguai, Uruguai, Bolívia e Argentina sentem-se comumente negligenciados pelo Brasil. Assim, apesar do peso relativo do Brasil, nas praças diplomáticas sul-americanas, não é óbvio que Brasília seja capaz ou tenha interesse em catalisar o ordenamento regional (SPEKTOR, 2010, p.29).

De acordo com SOARES DE LIMA (2013) existe ambiguidade entre analistas e lideranças políticas dos países vizinhos sobre essa questão. No mesmo instante em que temem a hegemonia brasileira, principalmente diante do peso econômico do país na América do Sul, setores políticos e acadêmicos criticam o pouco envolvimento do Brasil com a região e/ou desejam que o país assuma o seu papel de paymaster, ou seja, Brasília absorva os custos da integração através de maiores concessões na produção de bens coletivos regionais. No entanto, segundo BUENO (2010), o exercício da hegemonia ou mesmo liderança impõe elevados custos econômicos e financeiros para efetivação de projetos que unam a região em um destino comum e, a aceitação da liderança significa participar do futuro do líder. Porém, auxílios pontuais realizados pelo hegemon como forma de solidarizar-se com os objetivos de desenvolvimento das nações do seu entorno são insuficientes para superar resistências e desconfianças. E o Brasil tem graves problemas sociais que ofuscam o poder de atração e de referência para as sociedades locais. Além disso, não existe um consenso entre os brasileiros sobre que prioridades devem ser atribuídas à inserção do Brasil na América do Sul e, muito menos, a percepção das vantagens em tal liderança.

$41 \mathrm{Na}$ abordagem de SPEKTOR (2010), o Brasil tende atuar de maneira seletiva, voltado preferencialmente para o "interesse nacional" em vez de promover um amplo projeto que atenda as necessidades regionais. Para o autor, embora o país tenha institucionalizado diálogos em questões econômicas e de segurança e apoiado iniciativas de integração, o 
Brasil hesita em patrocinar instituições e normas regionais profundas que limitem sua autonomia face aos vizinhos. No mesmo contexto, a redondeza tampouco percebe na atitude do Brasil o desejo de desenvolver um projeto coletivo, principalmente quando o país exercita sua liderança ao acionar o poder de veto ${ }^{11}$ sobre iniciativas que prejudicam os interesses das empresas públicas e privadas brasileiras. Porém, segundo SOARES DE LIMA (2013), já em outras questões, o Brasil exerceu a liderança cooperativa. Isso poderia ser exemplificado pela criação do Fundo de Convergência Estrutural do MERCOSUL (FOCEM), a resposta conciliadora à nacionalização dos hidrocarbonetos pela Bolívia em 2006 e a renegociação com o Paraguai do acordo de Itaipu em 2009. Contudo, tal interpretação não encontrou consenso na literatura especializada que viu nessas atitudes brasileiras gestos de "generosidade", "ingenuidade", "indulgência" e "partidarização" (ALMEIDA: 2010; BUENO: 2010; BODINIER: 2014, entre outros).

Por outro lado, há uma preocupação acerca do grau de importância da integração regional na agenda da política externa brasileira, principalmente no momento em que o Brasil diversifica o seu horizonte geográfico. "O país não assume a posição de principal agente da ordem regional e hesita diante de situações onde é forçado a se impor. (...), especialmente quando isto significa pressionar vizinhos menores a respeitar o número crescente de regras formais que estrutura a vizinhança" (SPEKTOR, 2010, p.26). Assim, o ativismo regional brasileiro assume um caráter oscilante, ou seja, suas ações pontuais ora convergem a favor dos anseios de desenvolvimento dos países sul-americanos ora reacendem o temor das pretensões "imperialistas" de Brasília. Portanto, "a idéia de que o peso relativo do Brasil atrai (e não afasta) os vizinhos é relativamente nova e revela uma interpretação sobre o funcionamento do poder na região que valoriza uma dinâmica que a literatura especializada denomina bandwagoning"12 (SPEKTOR, 2010, p.37). No entanto, essa concepção do Brasil como "locomotiva" do processo integracionista esbarra tanto nas percepções divergentes da sociedade brasileira acerca da estrutura de governança regional quanto na aceitação dos demais governos do papel exercido pelo Brasil.

De fato, o governo brasileiro adensou o seu envolvimento em negociações multitemáticas no intuito de ressaltar a relevância do país nos foros globais. A estratégia do presidente Lula visava melhorar as capacidades de poder do Brasil articulando as ações políticas em diferentes escalas. Entretanto, a diplomacia do mandatário foi criticada por querer adotar as mesmas prerrogativas tanto para o plano regional quanto para o plano internacional, vistas como inconcebíveis por alguns autores (ALBUQUERQUE, 2009-2010; ALMEIDA, 2010; BUENO, 2010). Portanto, a condução da política externa no âmbito das relações globalregional nem sempre eram convergentes, pois a demasiada atenção as questões tratadas em várias arenas multilaterais ameaçava reduzir gradualmente a importância da América do Sul na agenda brasileira. Se isso ocorreu de fato, corroborou "com a posição de paciência estratégica e de complacência diante da paralisia da agenda econômica de cooperação e integração que caracterizou o governo Lula" (MOTTA VEIGA e RIOS, 2011, p.86-87).

44 A América do Sul, ao longo da década de 2000, passou a conviver com inúmeras iniciativas integracionistas promovidas pelo Brasil com intuito de mobilizar recursos para a concretização de uma governança regional. No entanto, o governo brasileiro não mostrou capacidade e/ou a vontade política de conduzir o regionalismo em alto perfil, com ações compartilhadas que enfrentassem os desafios comuns, como por exemplo, o combate ao tráfico de drogas; a expansão dos fluxos migratórios; a cooperação e integração de assuntos referentes à energia, ao meio ambiente, aos direitos humanos, entre outros. 
Também as relações intrarregionais esbarraram nas orientações político-ideológicas dos governos locais, nas assimetrias de suas economias e nas diferentes percepções dos países sobre inserção internacional. Assim, múltiplos arranjos e baixa unidade na discussão de temas comuns possibilitaram que potências extrarregionais e demais atores não-estatais ocupassem espaços no interior da região e projetassem seus interesses em busca de recursos naturais, de mercados e do aumento de poder nas escalas regional e mundial. Em razão disso, tomou impulso às relações triangulares Estados Unidos-Brasil-China que têm se constituído o vetor de desafio a liderança brasileira e aos processos de integração sulamericana.

Na avaliação de PECEQUILO (2013), podemos dividir cronologicamente as interações entre as três potências em dois momentos. Primeiro, o período referenciado a partir de 2000 até 2008, marcado pelo predomínio das ações Brasil-China e o segundo pela ofensiva norteamericana após a crise financeira de 2008, correspondendo o último ano do governo George W. Bush e a gestão de Barack Obama. Nesse contexto, ocorreu o encolhimento relativo brasileiro e a ascensão do país asiático. Quanto à relação Brasil-China, o governo de Benjing pautado numa política desenvolvimentista e "pacifista" nas relações internacionais, intensificou o diálogo com o eixo Sul-Sul. A intenção chinesa visava fortalecer a sua posição autônoma através de medidas que reduzissem as vulnerabilidades político-econômico-estratégicas frente aos Estados Unidos. Para isso, o governo pôs em prática a estratégia chamada de "going global", isto é, uma forma de apoio financeiro e logístico, dentre outras formas de ajuda, com o objetivo de incentivar as empresas chinesas a investirem no exterior. Assim, o poder público definia os setores que eram considerados essenciais para manutenção do crescimento, da modernização da economia e da estabilização social interna da China. Na América do Sul, o governo de Beijing assinou acordos comerciais com países da região cujo objetivo era torná-los consumidores de produtos manufaturados e fornecedores de matérias-primas e insumos energéticos. Além disso, procurava enfraquecer a proximidade de Taiwan com governos locais, evitando possíveis apoios futuros à declaração de independência taiwanesa.

Segundo os estudos do Instituto de Pesquisa Econômica Aplicada (IPEA) (2010), entre 2003 e 2008 o comércio chinês na região cresceu $700 \%$ no valor bruto enquanto, no mesmo período, as exportações brasileiras aumentaram 282,8\%. Em muitos mercados (Peru e Chile), a China já se tornou o principal destino das exportações, em outros, como o argentino e o venezuelano, o país asiático ameaça superar o Brasil na função de principal parceiro comercial. Os investimentos chineses na América do Sul vão principalmente para setores de recursos naturais como cobre, soja, minério de ferro e petróleo. Entretanto, para viabilizar o acesso a esses produtos e exportá-los, a China também canaliza recursos em direção a infraestrutura dos países (ferrovias, portos, rodovias, hidrelétricas, dentre outros). Na região é crescente a presença de empresas chinesas que injetaram bilhões de dólares tanto na compra de empresas locais quanto na formação de joint ventures com empresários sul-americanos.

47 A possibilidade de fazer negócios com os investidores estrangeiros tem levado os Chefes de Estado a adotar esforços mais contundentes para a concretização de acordos voltados para o potencial regional. Essas "vantagens comparativas" têm atraído a atenção de empresas e governos na exploração dos recursos naturais. É o que ressalta a reportagem de COSTA (2008, p.45) sobre os interesses diversificados dos chineses junto aos países:

[...]Chávez assinou em Pequim acordos para ampliar a exportação de petróleo de 364 mil para 500 mil barris/dia (esperando chegar em 2012 a 1 milhão , 38\% da atual 
produção venezuelana), construir uma nova refinaria de 300 mil barris/dia na Venezuela, três refinarias para petróleo venezuelano em Cantão e elevar de 6 bilhões para 12 bilhões o fundo de investimento conjunto dos dois países, a ser usado em infra-estrutura e projetos petrolíferos na Venezuela, ocupando o espaço abandonado pelas transnacionais anglo-americanas.

A China já compra mais de metade da soja e $30 \%$ do minério de ferro exportados pelo Brasil, $70 \%$ da soja em grãos e um terço do óleo da Argentina e 20\% do cobre do Chile. Tem projetos conjuntos com a Petrobras (petroquímica, tecnologia e exploração de águas profundas) e a Vale (CSV Baosteel, no Espírito Santo), investe 5 bilhões de dólares no setor petrolífero argentino, tem projetos de minério de ferro e gás na Bolívia, participa de empresas petrolíferas no Peru e Colômbia, vende armas para Cuba e se aproxima do Paraguai.

Nesse cenário de adensamento das relações econômicas sino-sul-americanas, a emergência chinesa ameaça redesenhar a geografia comercial do subcontinente, impactando os interesses das demais potências na região. A China em sua trajetória de projeção de poder em escala regional pôs em prática a tática de se tornar o parceiro central de cada país. Para isso, procura diminuir a influência dos demais poderes, em particular o Brasil e os Estados Unidos, privilegiando as relações econômicas como estratégia de aproximação junto aos Estados sul-americanos (PECEQUILO, 2013). O predomínio do capital chinês já é perceptível em determinados setores dos países, conforme os estudos do IPEA (2010). No Uruguai, produzem automóveis; no Peru e Venezuela, financiam obras de infraestrutura; no Chile, fomentam a pesca; na Colômbia, pretendem se associar na construção de um oleoduto de grandes proporções. Conquanto, o principal interesse dos chineses na América do Sul está associado aos recursos naturais e minerais, por isso a presença crescente nas licitações dos governos locais tem objetivo de dominar setores estratégicos e tornar-se um contraponto aos capitais norteamericanos e brasileiros. Entretanto, o governo de Beijing procura ampliar sua influência na região ao reafirmar repetidamente que a intenção chinesa é contribuir para estabilidade e prosperidade, portanto, não dá sinais de envolvimento em questões geopolíticas sul-americanas nas próximas décadas, confirmando a posição "pacifista" fora da Ásia-Pacífico.

49 A intensificação das relações sino-brasileiras não se limitou ao intercâmbio comercial e tecnológico, mas objetivava construir uma agenda comum que pudesse mitigar o peso político-econômico-militar dos Estados Unidos no cenário internacional. Assim, os governos de Brasília e de Beijing privilegiaram as ações bilaterais e multilaterais na intenção de solidificar parcerias em temas estratégicos e consolidar o eixo Sul-Sul como polo de poder alternativo a potência hegemônica. De acordo com CERVO (2008), as relações Brasil e China devem ser compreendidas a luz do que ele chamou de "parceria ascendente", ou seja, ela foi construída à base de vontade nacional, potencial similar e nível emparelhado de desenvolvimento alcançado. Por conseguinte, essa afinidade impulsionaria futuramente novas oportunidades que impactariam a economia brasileira $\mathrm{e}$ deixariam um legado tão relevante quanto à parceria constituída entre Brasil e Estados Unidos.

Embora esse eixo sino-brasileiro, por um lado, tenha trazido benefícios ao Brasil devido aos recursos direcionados ao agronegócio, a ampliação da infraestrutura, a instalação de montadoras de automóveis, a compra de papeis de empresas brasileiras como a Vale e a Petrobras, ou seja, colocado a relação dos dois no plano de prioridades e elevado a China ao patamar de principal parceiro comercial do Brasil, por outro, veio acompanhado de possíveis efeitos negativos de longo prazo, não só pela ameaça à especialização regressiva 
da pauta exportadora e da estrutura da indústria nacional, mas também, pela posição que os chineses assumem na percepção dos países sul-americanos, isto é, uma opção a assimetria geoeconômica e geopolítica entre o Brasil e a região.

51 A crise financeira de 2008 que assolou a economia norte-americana e contaminou muitos países europeus, levou os Estados Unidos a darem maior atenção a América Latina, principalmente a partir do governo de Barack Obama, embora esse mandatário continuasse a política externa de George W. Bush. A intenção do presidente Obama era tornar a região válvula de escape tanto às tensões econômicas quanto passível a introdução de medidas ordenadoras de segurança. Isso coincidiu com o momento da expansão chinesa e da projeção brasileira na América do Sul. Assim, a política de reafirmação da supremacia norte-americana não emergiu de "uma política construtiva para o continente ou que vise o aprofundamento da colaboração, mas sim de uma necessidade de preservar a zona de influência hemisférica e conter o avanço dos novos polos de poder nesta região e em escala mundial" (PECEQUILO, 2013, p.112). A política norte-americana visava transformar o mundo em campo de operações militares, no intuito de combater o terrorismo visto como uma ameaça de caráter global. Nesse cenário de instabilidade permanente, Washington põe em prática o modelo de reequilíbrio estratégico em diversas regiões, articulando os seus interesses econômicos à temática da segurança. Na América do Sul, o objetivo está balizado na renovação e ampliação das alianças no subcontinente como meio de conter a expansão das economias da China e do Brasil, já que essas potências através de suas empresas intensificariam a corrida pelos recursos naturais.

De acordo com BATTAGLINO (2009), o projeto hegemônico de Washington estruturou-se na projeção do poderio militar. No âmbito regional, as disputas pelos recursos naturais, principalmente os energéticos, e a deterioração da democracia foram combustíveis para que os Estados Unidos reativassem a IV Frota, fortalecessem o Comando Militar do Sul ( USSOUTHCOM) e criassem o Comando militar da África (USAFRICOM). O discurso de Washington estava pautado na construção de coalizões com países sul-americanos na intenção de dissuadir possíveis agressões aos mesmos. Porém, havia fortes desconfianças entre os Estados da região quanto às reais intenções estadunidenses. $O$ presidente Lula da Silva cogitou que tais medidas estariam relacionadas à descoberta de petróleo no litoral brasileiro. Por conseguinte, para os Estados Unidos, o Atlântico Sul tornou-se geoestratégico "devido à crescente presença brasileira, chinesa e indiana neste espaço, destacando-se sua relevância como zona de passagem e de produção de recursos energéticos (pré-sal, acesso a petróleo e gás) e de commodities" (PECEQUILO, 2013, p.112).

Nesse jogo de forças, os Estados Unidos reconfiguraram suas políticas e sua rede de posições militares de forma que lhe garanta responder de maneira preventiva qualquer tipo de ameaça. Para tanto, Washington desenvolveu um poderio tecnológico que dá ao país o controle concentrado de diversas regiões consideradas prioritárias tanto pela disponibilidade de recursos estratégicos quanto por necessitarem de atenção devido à presença de governos refratários as práticas norte-americanas (CECEÑA, 2008). Assim, ao voltar seus interesses em direção a América Latina, o governo estadunidense procura assegurar de maneira irrestrita o acesso aos territórios, utilizando-se do discurso de combate ao narcotráfico e das guerrilhas esquerdistas como as FARC-EP (Forças Armadas Revolucionárias da Colômbia - Exército do Povo) e o ELN (Exército de Libertação Nacional). Nesse sentido, a intenção perpassa pelo apoio orçamentário do Legislativo do país e da permissão de governos para que os Estados Unidos instalem/ampliem bases 
militares na região, as quais podem ser exemplificadas por aquelas materializadas no Plano Colômbia ${ }^{13}$. Portanto, a condução da política externa norte-americana para a América Latina pode ser compreendida a luz da influência dos códigos geopolíticos. De acordo com PINA (2007, p.102), a política externa de um Estado é moldada a partir de um código geopolítico em vigor, isto é, "um código é definido por diversas idéias conjugadas que explicam as intencionalidades de um Estado em relação a outros Estados, e ainda definem que tipo de conduta deve-se realizar para responder aos riscos que existem (ou são inventados) externamente".

54 A escalada militar introduzida nas relações intrarregionais pelo governo norte-americano não foi o único desafio aos processos de integração sul-americana. O fracasso da concretização da ALCA levou Washington a desenvolver acordos bilaterais, os chamados TLC's com países da região. Utilizando-se da assimetria econômica, os Estados Unidos procuraram alcançar maiores vantagens em assuntos como acesso a compras governamentais, investimentos e serviços financeiros, direitos de propriedade intelectual, e também acordos militares. Certamente, a intenção era contornar limitações impostas pela resistência do eixo Brasil-Argentina-Venezuela a proposta da Casa Branca, e apoiar novos projetos enquadrados na concepção do regionalismo aberto. Todavia, a recente formação da Aliança do Pacífico ${ }^{14}$ (México, Chile, Colômbia e Peru, dentre outros) que tem 209 milhões de habitantes e somatório do PIB de US\$ 2 trilhões contra 279 milhões de habitantes e PIB de US\$ 3,3 trilhões referentes ao MERCOSUL, acrescentou mais diversidade ao espaço regional ao ser visto como contraponto ao regionalismo pós-liberal. Tais países da Aliança já possuem vínculos com os Estados Unidos e a constituição dessa proposta instala uma possível competição entre dois modelos. SOARES DE LIMA (2013, p.186), ressalta que esse projeto dá mais visibilidade ao grupo de países que "enfatizam as soluções de mercado, a liberalização comercial e a integração às cadeias produtivas globais, com políticas externas mais convergentes com os Estados Unidos e favoráveis ao status quo da governança global". Essa percepção põe em xeque a proposta denominada pós-liberal encaminhada por iniciativas bastante heterogêneas como a CASA, a UNASUL e a ALBA. Esse regionalismo pós-neoliberal procura reduzir o peso dado à dimensão comercial e ressaltar outras temáticas na agenda, principalmente aquelas que resgatam o desenvolvimento e/ou a equidade, segundo a anuência da administração estatal.

Neste contexto, as iniciativas de integração propostas nas décadas de 1990 e de 2000 perderam fôlego e estão fragilizadas diante das expectativas de países da América do Sul em busca de inserção nos mercados globais. Assim, a possibilidade de articular a região sul-americana à dinamicidade das economias asiáticas tem ameaçado produzir clivagens no subcontinente entre posições liberais e nacionalistas, o que favoreceriam, sobretudo, a influência política e econômica de potências extrarregionais e de suas grandes corporações transnacionais no subcontinente. Desse modo, a Aliança do Pacífico serviria como um instrumento para a projeção de poder norte-americano no intuito de frear a ascensão chinesa na América do Sul e possivelmente na Bacia do Pacífico - instituindo outra ordem geoeconômica no Arco do Pacífico. Por conseguinte, o apoio a um projeto de integração regional neoliberal esvaziaria a importância das iniciativas regionais lideradas pelo Brasil, principalmente o MERCOSUL e a UNASUL, e manteria a fragmentação regional (PADULA, 2013). 


\section{Conclusão}

57 Ao analisarmos a relevância da escala internacional nas gestões do governo Lula da Silva, observamos que o objetivo era diversificar o vetor de atuação do país no cenário global e consolidar a liderança regional, para isso era fundamental elevar a política externa à categoria dos temas prioritários na agenda brasileira. Assim, houve o redimensionamento do status quo do Ministério das Relações Exteriores e a ingerência da diplomacia presidencial nos assuntos internacionais. Em termos gerais, ocorreu uma mudança de percepção sobre a capacidade de atuação do país nos assuntos externos por meio de postura mais autônoma e pela diversificação das parcerias estratégicas, principalmente sustentadas no diálogo horizontal Sul-Sul. Nesse contexto, a orientação da política externa do governo Lula estava voltada para a promoção de oportunidades para o capital doméstico. Então, a postura governista era enfatizar a cooperação com os países da América do Sul como plataforma de expansão dos negócios brasileiros. Dessa forma, a integração tornou-se tema recorrente no Itamaraty e no ativismo do presidente Lula que conferiram densidade aos acordos regionais.

Embora a América do Sul ocupe posição prioritária na agenda brasileira, assistimos atualmente a inflexão de alguns países em direção a outras potências e regiões. 0 adensamento das relações intrarregionais visíveis na década de 1990 e início dos anos 2000 acentuou as assimetrias econômicas com vantagens expressivas ao Brasil. Certamente, a região possui relevância na pauta de exportação brasileira, principalmente de manufaturas, mas, também, é o principal destino de investimentos de empresas nacionais, além dos vários projetos de cooperação em diversas temáticas. 0 potencial mercado brasileiro poderia representar oportunidades aos países vizinhos e criar interdependências, afastando a ingerência de potências externas em assuntos regionais e as propostas cunhadas no regionalismo aberto. No entanto, a busca do governo Lula da Silva de circunscrever o país na esfera internacional relativizou a importância do subcontinente na política externa brasileira. Essa atenção vacilante em relação ao seu "entorno geográfico imediato" tem permitido que potências extrarregionais aumentem o seu peso na América do Sul e desloque a liderança brasileira para a retórica. Somados a isso, a relação entre Brasil e países sul-americanos enfrenta desafios tanto em virtude das iniciativas integracionistas que ameaçam não "decolar" quanto no aprofundamento dos focos de tensão política nos territórios dos países vizinhos, já que os crescentes investimentos de empresas brasileiras, financiadas pelo BNDES, em setores de energia e recursos naturais têm causado impactos sociais e ambientais nos países onde estão disseminadas. 


\section{BIBLIOGRAFIA}

ALBUQUERQUE, José Augusto Guilhon. O regionalismo do governo Lula e as percepções das elites sul-americanas. In: Revista Política Externa - Vol. 18 n.3 - Dez/Jan/Fev, SAP Paulo: Paz e Terra, 2009-2010, p.15-32.

ALMEIDA, Paulo Roberto de. Pensamento e ação da diplomacia de Lula: Uma visão crítica. In: Revista Política Externa, vol.19, n.2, set/out/nov., São Paulo: Paz e Terra, 2010, p.27-40.

BATTAGLINO, Jorge. A reativação da IV Frota e o novo paradigma de controle global dos Estados Unidos. In: Revista política Externa, vol.17, n.4, Mar/Abr/Mai, São Paulo: Paz e Terra, 2009, p. 31-45.

BODINIER, Gérard. A política externa do Brasil 2003-2013: depois da esperança suscitada e do papel de destaque exercido, o país se encontra em certo isolamento?. In: Revista Política Externa, vol.22, n.4, abr/mai/jun., São Paulo: HMG editora, 2014, p.37-52.

BOITO JUNIOR, Armando \& BERRINGER, Tatiana. Brasil: classes sociais, neodesenvolvimentismo e política externa nos Governos Lula e Dilma. In: Revista de Sociologia e Política, Curitiba, v. 21, no 47: set. 2013, p.31-38.

BUENO, Clodoaldo. O entorno geográfico na diplomacia brasileira dos séculos XX e XXI. In: Revista Política Externa, vol. 19, n.2 - set/out/nov, São Paulo: Paz e Terra, 2010, p.41-54.

CAMPOS, Carlos Oliva. A América do Sul na encruzilhada da sua história: fragmentação, alternativas políticas e opções a partir da periferia. In: Novas lideranças políticas e alternativas de governo na América do Sul / Luis Fernando Ayerbe (org.), SP : editora UNESP,/UNICAMP/ PUC-SP, 2008, p.199-233.

CECEÑA, Ana Esther. Sujeitando o objeto de estudo, ou da subversão epistemológica como emancipação. In: CECEÑA, Ana Esther (Org.). Os desafios das emancipações em um contexto militarizado. São Paulo: Expressão popular, 2008.

CERVO, Amado L.\& BUENO, Clodoaldo. História da política exterior do Brasil. 4 a ed. rev. ampl., Brasília: Editora UNB, 2012.

CERVO, Amado L. Inserção internacional: formação dos conceitos brasileiros, São Paulo: Ed. Saraiva, 2008.

, Amado L. Relações Internacionais do Brasil: um balanço da era Cardoso. In: Revista Brasileira de Política Internacional 45(1): 2002, p.5-35.

COSTA, Antonio Luiz C. Quebra de monopólio - latinos buscam apoio na Rússia, na China ou entre si, em desafio à hegemonia dos EUA e à Doutrina Monroe. Revista Carta Capital - Seção: Nós e o mundo - 11/10/2008.

DUPAS, Gilberto \& OLIVEIRA. Marcelo Fernandes. A União Sul-Americana de Nações: Oportunidades econômicas e entraves políticos. In: AYERBE, Luis Fernando (Org.), Novas lideranças políticas e alternativas de governo na América do Sul, São Paulo: UNESP, 2008, p.235-263.

FLORES, Mario César. Possibilidades e riscos da união regional, Rio de Janeiro, CEBRI - Artigos, vol. 2, Ano I - Abril-Junho, 2006. 
FUNDAÇÃO ALEXANDRE DE GUSMÃO. Brasil. Presidente (2003 - : Lula). Discursos selecionados do Presidente Luiz Inácio Lula da Silva, Brasília: FUNAG, 2008.

GALVÃO, Thiago Gehre. América do Sul: construção pela reinvenção (2000-2008). In: Revista Brasileira de Política Internacional, v.52, n.2, 2009, p.63-80.

GISBERT, Carlos Mesa. Bolívia e Brasil: Os meandros do caminho. In: Revista Política Externa, vol.20, n.2, set/out/nov., São Paulo: Paz e Terra, 2011, p.23-41.

HIRST, Monica, SOARES DE LIMA, Maria Regina \& PINHEIRO, Letícia. A política externa brasileira em tempos de novos horizontes e desafios. In: Observatório Político Sul-Americano - análise de conjuntura n.12, dez.2010, p.1-19.

HURRELL, A. O Brasil e os Estados Unidos: reflexões comparativas. In: HIRST, M. (org.) Brasil Estados Unidos: desencontros e afinidades. Rio de Janeiro: FGV, 2009.

INSTITUTO DE PESQUISA ECONÔMICA APLICADA. Inserção internacional brasileira: temas de política externa, Livro 3 vol. 1, Brasília: IPEA, 2010.

LECHINI, Gladys. O “Sul” para além da Geografia, a acepção política e econômica do termo. In: , n.459 - Ano XIV, Porto Alegre: UNISINOS, 2014, p.20-23.

LESSA, Antonio Carlos, COUTO, Leandro Freitas \& FARIAS, Rogério de Souza. Política externa planejada: os planos plurianuais e a ação internacional do Brasil, de Cardoso a Lula (1995-2008), In: Revista Brasileira de Política Internacional, Ano 52, nº1, Brasília: IBRI, 2009, p.89-109.

MOTTA VEIGA, Pedro da. \& RIOS, Sandra Polônia. O Brasil como vetor de integração sulamericana: possibilidades e limites. In: Revista Política Externa, vol. 20, n.2, set/out/nov, São Paulo: Paz e Terra, 2011, p.73-94.

PADULA, Raphael. A Aliança do Pacífico, o Brasil e o poder global na integração regional da América do Sul. In: $4^{\circ}$ Encontro Nacional da Associação Brasileira de Relações Internacionais, Belo Horizonte, 2013, p.1-18.

PECEQUILO, Cristina Soreanu. A América do Sul como espaço geopolítico e geoeconômico: 0 Brasil, os Estados Unidos e a China. In: Revista Carta Internacional, vol. 8, n.2, jul-dez, São Paulo: ABRI, 2013, p.100-115.

. A Política Externa do Brasil no Século XXI: Os Eixos Combinados de Cooperação Horizontal e Vertical In: Rev. Bras. Polít. Int. 51 (2): 136-153 [2008]

PINA, Rodrigo. Territorialização militar em rede e o imperialismo estadunidense na América Latina: um novo código geopolítico? Dissertação de Mestrado. Niterói: Programa de PósGraduação em Geografia da Universidade Federal Fluminense, 2007. 190p.

POULANTZAS, Nicos. As classes sociais no capitalismo de hoje, Rio de Janeiro: Ed. Zahar, 1978.

RUSSEL, Roberto \& TOKATLIAN, Juan Gabriel. Argentina diante da ascensão do Brasil: percepção e estratégias. In: Revista Política Externa, vol.23, n. 2 - out/nov/dez, São Paulo: HMG editora, 2014, p.35-47.

SARAIVA, Miriam Gomes. Integração regional na América do Sul: processos em aberto. In: Observatório Político Sul Americano, n.7, julho, Rio de Janeiro: IESP/UERJ, 2010, p.1-18.

Miriam Gomes. As estratégias de cooperação Sul-Sul nos marcos da política externa brasileira de 1993-2007, In: Revista Brasileira Política Internacional, vol.50, n.2, Rio de Janeiro, 2007, pp. 42-59.

SICSÚ, João, PAULA, Luiz Fernando de. \& MICHEL, Renaut. Por que novo- desenvolvimentismo? In: Revista de Economia Política, vol. 27, no 4 (108), outubro-dezembro/2007, p.507-524. 
SOARES DE LIMA, Maria Regina. Relações interamericanas: A nova agenda sul-americana e o Brasil. In: Revista Lua Nova, n.90, São Paulo, 2013, p.167-201.

SOARES DE LIMA, Maria Regina. \& DUARTE, Rubens. S. Diplomacia presidencial e politização da política externa: Uma comparação dos governos FHC e Lula. Observador On-Line, v, 8, n. 9. Rio de Janeiro: Observatório Político Sul-Americano - IESP/ UERJ, 2013.

SOARES DE LIMA, Maria Regina \& HIRST, Monica. A iniciativa IBAS e a cooperação Sul-Sul: Desafios intelectuais e possibilidades políticas. In: SOARES DE LIMA, Maria Regina \& HIRST, Monica (Orgs.). Brasil, Índia e África do Sul: desafios e oportunidades para novas parcerias, São Paulo: Paz e Terra, 2009, p. 7-28.

SORJ, Bernardo \& FAUSTO, Sergio. O papel do Brasil na América do Sul: estratégias e percepções mútuas. In: Revista Política Externa, vol. 20, n.2 - set/out/nov, São Paulo: Paz e Terra, 2011, p.11-22.

SPEKTOR, Matias. Ideias de ativismo regional: A transformação das leituras brasileiras da região. In: Revista brasileira de Política Internacional, 53 (1), Brasilía, 2010, p.25-44.

VIGEVANI, Tullo, RAMANZINI JÚNIOR, Haroldo \& CORREIA, Rodrigo A. Relação entre política doméstica e integração regional: Uma interpretação do Brasil no Governo Lula da Silva. In: AYERBE, Luis Fernando (Org.). Novas lideranças políticas e alternativas de governo na América do Sul, São Paulo: Editora UNESP, 2008, p.83-115.

VIGEVANI, Tullo \& CEPALUNI, Gabriel. A política externa de Lula da Silva: a estratégia da autonomia pela diversificação. In: Revista Contexto internacional, Rio de Janeiro, vol. 29, n. 2, p. 273-335, julho/dezembro 2007.

VISENTINI, Paulo G. Fagundes. A projeção internacional do Brasil: 1930-2012: diplomacia, segurança e inserção na economia mundial, Rio de Janeiro: Elsevier, 2013.

Paulo G. Fagundes - O Brasil e o mundo: a política externa e suas fases - Revista

Ensaios FEE, v.20, n.1. Porto Alegre: FEE, 1999, p. 134-154.

\section{NOTAS}

1. O novo-desenvolvimentismo incorporou temas que ficaram relegados ao segundo plano no período desenvolvimentista, como o da dimensão social e da expansão do mercado interno de consumo, juntamente aos elementos da estabilidade econômica, implementados pelo neoliberalismo. Essa combinação foi ressaltada no trabalho de SICSÚ et al ( 2007), ao centrar suas percepções nos seguintes eixos: (i) na estabilidade macroeconômica e na redução das vulnerabilidades externas, garantidas pela manutenção de uma taxa de câmbio competitiva, coordenada com as demais esferas da política macroeconômica; (ii) na existência de um empresariado nacional forte e de investimento em inovação técnica; (iii) no crescimento econômico elevado e continuado para redução das desigualdades e (iv) na adoção de políticas sociais universais, com o objetivo de reduzir as assimetrias sociais e potencializar o capital humano.

2. "A ideia de promover a cooperação entre os países do Sul surgiu como complemento e ao mesmo tempo como alternativa à relação assimétrica Norte-Sul. O processo de aproximação entre os países da América Latina e da África se dá no contexto das relações Sul-Sul. Mas o conceito 'Sul' ultrapassa a categoria geográfica e se assenta sobre uma concepção política e econômica. Os países do Sul são países em vias de desenvolvimento, periféricos, que compartilham situações socioeconômicas e político-culturais tanto entre seus contextos locais 
como nos âmbitos regionais. No entanto, podem aspirar a manter relações mais igualitárias e cooperativas, compartilhando experiências e somando força política e econômica para ganhar mais autonomia na hora de organizar a agenda global e defender seus interesses" (LECHINI, 2014, p. 21).

3. Segundo SOARES DE LIMA e DUARTE (2013), as viagens presidenciais representaram o grau de importância que o governo brasileiro atribuiu a outro país ou mesmo a um Continente. Embora o número de visitas não ilustra, em última instância, a relevância e a profundidade das conversas. No entanto, a visita oficial do Presidente da República a um país vizinho ou distante de sua região revela a existência de uma vontade política de maior estreitamento dos laços políticos.

4. O eixo horizontal é representado pelas parcerias com as nações emergentes, por suas semelhanças como grandes Estados periféricos e países em desenvolvimento como Índia, China, África do Sul e a Rússia (sendo que informalmente, o Brasil, a Rússia, a Índia e a China formam o chamado bloco BRIC). A agenda é composta também pelos países menos desenvolvidos (LDCs) da África, Ásia e Oriente Médio, cujo poder relativo é menor do que o brasileiro. Este eixo representa a dimensão terceiro-mundista da política externa, também definida como relações Sul-Sul. Os benefícios potenciais deste eixo são econômicos, estratégicos e políticos (PECEQUILO, 2008, p.145).

5. Aqui, podemos utilizar como caso emblemático dessa relação à contenda envolvendo Brasil e Equador em relação às falhas graves na obra da hidrelétrica San Francisco, construída pela Odebrecht. As ameaças do governo equatoriano de suspender o pagamento da mesma levaram o presidente Lula a colocar aquele país na "geladeira" para futuros empréstimos do BNDES.

6. “A hipótese básica do regionalismo pós-liberal é que a liberalização dos fluxos de comércio e investimentos e sua consolidação em acordos comerciais não apenas não são capazes de gerar 'endogenamente' benefícios para o desenvolvimento, mas ainda podem reduzir substancialmente o espaço para a implementação de políticas nacionais 'de desenvolvimento' e adoção de uma agenda de integração preocupada com temas de desenvolvimento e de equidade" (MOTTA VEIGA e RIOS, 2011, p.84).

7. "É importante lembrar que os Estados Unidos estavam empenhados em criar a ALCA nos mesmos moldes do NAFTA, acordo que, aos olhos do Brasil, reduziria o México à condição de apêndice da economia norte-americana. Com esta ameaça em vista, o governo brasileiro percebia na integração regional e, particularmente no MERCOSUL, um sistema de proteção e uma plataforma para assegurar condições que permitissem ao Brasil realizar todo o seu potencial de global player" (SORJ e FAUSTO, 2011, p.12).

8. O Brasil vem tendo divergências com os países vizinhos em virtude das formas de condução de suas empresas nos projetos de desenvolvimento locais. Observamos esses problemas no Equador com a empresa Odrebrecht; na Bolívia com a nacionalização das instalações da Petrobrás e no Paraguai com a revisão do Tratado de Itaipu.

9. Na análise de SOARES DE LIMA (2013, p.197), geralmente a liderança é entendida por pesquisadores tanto na capacidade influenciar terceiros quanto reconhecê-los. Porém, a complexidade de mensurar o grau de influência sobre terceiros pode confundir conceitualmente liderança com reconhecimento. Portanto, para estabelecer a diferença, a autora sugeriu que "se defina liderança não como influência sobre terceiros, mas como influência sobre os resultados. (...) Essa é exatamente a definição de um ator com poder de veto: aquele sem cuja anuência um acordo, iniciativa, ou negociação não se realizam".

10. Carlos Mesa GISBERT (2011) interpreta a relação Brasil-Bolívia como preocupante devido à excessiva dependência do seu país a economia brasileira, promovendo resistências a um possível "imperialismo" do seu vizinho do Leste.

11. "De fato, o Brasil tem sido um ator de veto nas questões financeiras, tomando-se como evidência as resistências do BNDES à criação de um Banco do Sul e sua exigência quanto ao cumprimento das normas técnicas em todas as questões de financiamento. Por não ter interesse 
no projeto, a Petrobras também foi um ator de veto à proposta da Venezuela de construção do gasoduto ligando o norte ao sul da América do Sul" (SOARES DE LIMA, 2013, p.197).

12. Segundo HURREL (2009), tal estratégia representa o ato de se aliar ao país ou coalizão mais forte. Esse comportamento se diferencia da posição do "balanceamento" que é o ato de unir forças contra os mais poderosos.

13. Segundo CECEÑA (2008, p.22), as bases norte-americanas se multiplicaram dentro da Colômbia e foram distribuídas geoestrategicamente para cobrir a área do país e, ao mesmo tempo, a fronteira com a Venezuela. Essas bases estão incorporadas "a FOL (Forward Operating Locations) em Aruba-Curaçao para controlar o passo do Darién que conecta a Colômbia com o Panamá, a entrada da sela amazônica e a saída do petróleo venezuelano para o oeste".

14. De acordo com PADULA (2013, p.7-8), “a Aliança do Pacífico, firmada em 06 de junho de 2012, também é uma iniciativa primeiramente do Peru, reforçada pela Colômbia, envolvendo também Chile e México. Conta com o apoio dos EUA, e poderá contar com adesão em breve de Panamá, Costa Rica, Japão e Indonésia. Já conta com o Uruguai como observador e o Paraguai sinalizou que deseja se tornar um observador, ambos países do MERCOSUL".

\section{RESUMOS}

A crescente presença brasileira no espaço regional, em especial, após a primeira eleição do presidente Lula da Silva, reacendeu os debates sobre a retomada do projeto do país à condição de "potência regional" e "global". As discussões estiveram pautadas nas ações políticas, econômicas, sociais, militares e culturais colocadas em curso pelo Brasil, e sustentadas na articulação entre a agenda doméstica e a estratégia de inserção internacional. Tal intento passava pela constituição de uma diplomacia ativa e afirmativa, por isso era fundamental fortalecer as relações com os países vizinhos, consolidar a América do Sul como área prioritária na agenda nacional e superar o baixo perfil sul-americano na função de eixo alternativo de poder na escala mundial.

La creciente presencia brasileña en el espacio regional, en especial, después de la primera elección de presidente Lula da Silva, reaccionó las discusiones sobre volver a tomar del proyecto del país a la condición "potencia regional" y "global". Las peleas habían sido pautadas en las políticas de las acciones económicas, sociales, militares y culturales, colocado en el curso para el Brasil, y apoyadas en el articulación entre la agenda doméstica y la estrategia de la inserción internacional. Tal intención pasada para la constitución de una diplomacia activa y afirmativa, por lo tanto era básico fortificar las relaciones con los países vecinos, consolidar la América del Sur como área de prioridad en la agenda nacional y sobrepasar el perfil bajo americano del sur en la función del árbol alternativo de poder en la escala mundial.

Les croissantes interventions politiques, économiques, militaires, sociaux et culturelles du Brésil dans l'Amérique du Sud - surtout après le premier gouvernement Lula da Silva - a repris la condition brésilienne de «puissance régionale» et même «globale». Dans ce contexte, la diplomacie brésilienne a renforcé les liens avec les pays voisins à fin de consolider l'Amérique du Sud en tant qu'espace prioritaire de ses intérêts.

The growing Brazilian presence in the regional space, especially after the first election of President Lula da Silva, reignited the debates about the resumption of the country's project to the status of "regional power" and "global power." The discussions were based on the political, 
economic, social, military and cultural actions put in place by Brazil, and based on the articulation between the domestic agenda and the international insertion strategy. Such attempt went through the constitution of an active and affirmative diplomacy, so it was essential to strengthen relations with neighboring countries, to consolidate South America as a priority area in the national agenda and to overcome the low South American profile as an alternative axis of power on a global scale.

\section{ÍNDICE}

Mots-clés: politique extérieure, puissance régionale, Amérique du Sud, Lula da Silva, rapports Sud-Sud

Keywords: Foreign policy - South America - Lula da Silva - South-South relations.

Palabras claves: Política externa - América del Sur - Lula da Silva - relaciones Sur-Sur

Palavras-chave: Política externa - América do Sul - Lula da Silva - Relações Sul-Sul.

\section{AUTOR}

\section{JORGE LUIZ RAPOSO BRAGA}

Professor Doutor do Departamento de Geografia da Universidade do Estado do Rio de Janeiro Faculdade de Formação de Professores - São Gonçalo - RJ. Professor do Colégio Naval - Angra dos Reis - RJ. Doutorado em Geografia na Universidade Estadual de Campinas. 